\title{
Socioeconomic status and dental wear - A correlation
}

\author{
Hasan Baber ${ }^{*}$, Kashif Aslam ${ }^{1}$, Zia Abbas ${ }^{1}$, Rizwan Nadeem $^{2}$ and Muznah Khalid ${ }^{1}$ \\ ${ }^{1}$ Dow University Of Health Sciences, Karachi, Pakistan \\ ${ }^{2}$ Private Dental Practitioner, BDS,Msc(Uk)
}

\begin{abstract}
Objective: To evaluate an association of dental wear among different socio economic groups

Methodology: It was a cross sectional study conducted in dental OPD of Dow University of Health Sciences. A custom design questionnaire was developed to assess the tooth wear among different social classes by questions directly and indirectly related to dental wear. Sample size was calculated via software OPEN API, and considering patient turnover in opd over a 10 months' period. Sample size was 400. Study was conducted during the period of March 2016 to Jan 2017. Socioeconomic groups were divided into Upper, Middle and Lower class. Data was analyzed through SPSS Ver 21.
\end{abstract}

Results: Results showed Poor socioeconomic group to be the most effected by tooth wear, except for chewing habits which were almost same among all social classes. Possible reasons include lack of awareness, knowledge and education regarding predisposing factors for tooth wear

Conclusion: Current data evaluating SES with tooth wear is lacking. Many confounding variables were overlooked in present study and can be studied further in finding association between SES and tooth wear

\section{Introduction}

Attrition, Erosion and Abrasion together constitute tooth wear. Patient must also be able to understand the general concept of tooth wear (Loss of tooth surface) so patient can relate his condition to dentist and receive appropriate treatment.

Concept of socioeconomic differences in Dental health can be defined as differences in incidence or prevalence of dental health issues among individuals of lower and higher socioeconomic status [1].

There is well established link between socioeconomic status and oral health. A number of previous research studies showed health of individuals belonging to poor socioeconomic status is much worse than those belonging to upper social class [2].

This relationship persists over a wide range of health indicators, which also includes oral health [3].

There has been extensive work on tooth wear regarding its prevalence and etiology [4,5]. A study in Malaysia on tooth wear with respect to age revealed majority of studied group having tooth wear in one form or another [6].

Increase intake of citrus drinks, refined and processed food is observed to increase in developing countries, which has cause change in dietary pattern among people and resultant increase incidence of caries and tooth wear $[7,8,9]$.

Majority of previous work had been focus on association of tooth wear with age, gender and ethnicity [10]. Although there is lack of evidence on association of tooth wear and Socioeconomic status [11]. A study by Millward et al, demonstrated increased incidence of tooth wear among higher socioeconomic status group children [12]. Majority of studies reporting tooth wear association with socioeconomic status are on school going children [13,14]. A study by Al-Dlagian et al showed increase tooth wear among lower Socioeconomic group children [15].
Considering lack of similar studies in Pakistan, aim of present study was to evaluate association of tooth wear among different socioeconomic groups coming in dental opd of Dow University of Health Sciences, Karachi. We hypothesize that attrition and Erosion is associated with lower socioeconomic groups.

\section{Methodology}

It was a cross sectional study, with random type of sampling technique used. The study took place in Dental OPD of Dow University of Health Sciences, Karachi during the period of March 2016 to Jan 2017. Personal consent was taken from participants. Inclusion criteria for the study was patients above age of 15 years (with mean age 30 years), both males and females and are representative of middle, rich or poor social economic class of Pakistan, having at least 12 scorable teeth present and be able to understand English, Urdu and local languages of Pakistan. Exclusion criteria was patients who are not nationals of Pakistan, edentulous patients, wearing prosthesis, many dental restorations and those patients who had any physical or mental disability which might had interfere in interview process. Questionnaire was custom made, with variables pertaining to frequency of self inflicted habits such as nail biting, drinking of acidic drinks, GERD associated tooth erosion, and perception of tooth sensitivity (Patient feeling hot and cold sensation during food intakes) were adapted from Sun.K et al [16]. A number of indicators were used in accessing socioeconomic status. Most common indicators included status of occupation, salary and education level. Each indicator usually covers a different aspect of social stratification

Correspondence to: Hasan Baber BDS,Msc(UK),Pg Dip(UK),MBA(UK), Assistant Professor, Dow University of Health Sciences, Karachi, Pakistan, E-mail: relicpassion@yahoo.com

Key words: socioeconomic status, dental wear, gastroesophageal reflux disease, tooth erosion, social Class

Received: June 22, 2017; Accepted: July 20, 2017; Published: July 24, 2017 
thus in line with previous studies we used all three instead of one. If on certain circumstances information related to salary, occupation and education was not available than other proxy measures were used such as indicators of living style, example ownership of car which directly reflects financial support of an individual [17]. Participants were interviewed by field investigators including Dental House Officers (also coauthors). General examination instruments were used including mouth mirror and probe by House officer in Diagnosis department for accessing tooth wear.

\section{Results}

Results of study are tabulated in tables 1-5.

In line with the results we accept our null hypothesis "There is an association between attrition and erosion with lower Socioeconomic class".

\section{Discussion}

Our study demonstrated lower social class complaining of teeth sensitivity (hot and cold sensation), much more than middle and upper social class age groups. Previous studies have reported high prevalence of dental sensitivity and pain among low Socio economic

Table 1. Teeth sensitive

\begin{tabular}{|c|c|c|c|c|c|}
\hline \multirow{2}{*}{$\begin{array}{c}\text { Teeth are } \\
\text { becoming } \\
\text { sensitive }\end{array}$} & \multicolumn{3}{|c|}{ Socioeconomic Status } & Total & P value \\
\cline { 2 - 6 } & Rich & Middle Class & Lower Class & & \\
\hline Yes & 2 & 76 & 178 & 256 & 0.003 \\
\hline No & 4 & 62 & 78 & 144 & \\
\hline Total & 400 & & & & \\
\hline
\end{tabular}

Table 2. Nail biting

\begin{tabular}{|c|c|c|c|c|c|}
\hline \multirow{2}{*}{$\begin{array}{c}\text { Habit of } \\
\text { nail biting }\end{array}$} & \multicolumn{3}{|c|}{ Socio economic Status } & Total & P value \\
\cline { 2 - 6 } & Rich & Middle Class & Lower Class & & \\
\hline Yes & 2 & 18 & 36 & 56 & 0.374 \\
\hline No & 4 & 120 & 220 & 344 & \\
\hline Total & 400 & & & & \\
\hline
\end{tabular}

Table 3. Chewing preferences

\begin{tabular}{|c|c|c|c|c|c|}
\hline \multirow{2}{*}{$\begin{array}{c}\text { Chewing } \\
\text { Preferences }\end{array}$} & \multicolumn{3}{|c|}{ Socioeconomic Status } & Total & P value \\
\cline { 2 - 6 } & Rich & Middle Class & Lower Class & & \\
\hline Unilateral & 76 & 45 & 69 & 190 & 0.163 \\
\hline Bilateral & 30 & 80 & 100 & 210 & \\
\hline Total & & & & & 400 \\
\hline
\end{tabular}

Table 4. Acidic drinks

\begin{tabular}{|c|c|c|c|c|c|}
\hline \multirow{2}{*}{$\begin{array}{c}\text { Consuming } \\
\text { acidic drinks }\end{array}$} & \multicolumn{3}{|c|}{ Socio Economic status } & Total & P value \\
\cline { 2 - 6 } & Rich & Middle Class & Lower Class & & \\
\hline $\begin{array}{c}\text { Daily } \\
\text { /3 times / } \\
\text { week }\end{array}$ & 2 & 20 & 30 & 52 & 0.02 \\
\hline $\begin{array}{c}\text { Multiple } \\
\text { times /Month }\end{array}$ & 0 & 36 & 48 & 84 & \\
\hline Once a month & 4 & 48 & 154 & 206 & \\
\hline Total & 400 & & & & \\
\hline
\end{tabular}

Table 5. GERD

\begin{tabular}{|c|c|c|c|c|c|}
\hline \multirow{2}{*}{$\begin{array}{c}\text { Do you have } \\
\text { Gerd }\end{array}$} & \multicolumn{3}{|c|}{ Socioeconomic Status } & Total & P value \\
\cline { 2 - 6 } & Rich & Middle Class & Lower Class & & \\
\hline Yes & 2 & 28 & 74 & 104 & 0.163 \\
\hline No & 4 & 110 & 182 & 296 & \\
\hline Total & 400 & & & & \\
\hline
\end{tabular}

group $[18,19,20]$. Earlier reports have suggested, that it is only when sensitivity interferes in oral health related quality of life, that patients seek dental treatment [21].

Individuals having increased level of dental related anxiety are known to have the lowest oral health related quality of life [22], as in line with our findings. Another similar study reported individuals from low SES, having worst oral health condition and thus high chance to endure pain and sensitivity then those in upper SES.

Certain oral parafunctional habits such as nail biting are known to result in occlusal tooth wear [23]. A study by Brekhna Murad et al found parafunctional habits such as nail biting to be prevalent among high socioeconomic class [24]. In line with present study Rabab M Fateih reported prevalence of parafunctional habit to be higher in people of low socioeconomic group [25]. Our findings can be attributed due to poverty, lack of health facilities, poor health and above all lack of awareness. Majority of people do not report the issue, until and unless it interferes with their oral health well-being. Another reason to nail biting is stress. Poor socioeconomic class can have episodes of stress due to number of reasons such as financial, employment, social etc that can predispose to this parafunctional habit and subsequent occlusal wear.

Present study demonstrated increased consumption of acidic drinks by low socioeconomic group. A study in UK found an association between soft drinks and dental erosion to be more pronounced in lower income group [26]. Possible cause can be lack of awareness regarding harmful effect of acidic drinks on tooth by this particular social class.

An interesting observation of present study is GERD effect on low socioeconomic class. GERD associated dental erosion was reported more in lower income and low level of education. These results were also reported by Menachem $M$ et al [27]. Previous studies reported increase GERD among individuals having low level of education $[28,29]$. German study by Nokon et al also reported similar results. Possible underlying causes for these observations is individuals belonging to poor social economic class have lifestyle associated risk factors like obesity and smoking. Although Nokon et al in his study has observed even after adjustment of BMI and smoking, individuals belonging to poor or middle social class had almost doubled the risk for severe GERD symptoms [30].

With regards to chewing habits, Unilateral chewing is known to be a causative factor for tooth wear [31]. Our study demonstrated increased tooth wear as a result by unilateral chewing reported almost equal among all social classes with slighter higher findings in upper socioeconomic class. Unilateral chewing results in higher impact force on the preferred side of chewing, resulting in greater occlusal contact and subsequent tooth wear and dentin exposure [32]. In present study, almost $47 \%$ of participants preferred Unilateral chewing, this is in accordance with study reported by Zhang $J$ et al who reported $46.8 \%$ unilateral chewing preference among his study group [33]. No significant association was found with regards to socioeconomic status and preferred chewing habits, as studies have reported it as a personal choice not associated with status of an individual.

\section{Conclusion}

Present study has demonstrated certain triads to be associated with socioeconomic status probably Poor social class, as this is the class most commonly effected due to lack of awareness, knowledge and poor oral hygiene condition. 


\section{Acknowledgement}

The author would like to thank dental house officers for their participation to complete the research process.

\section{Conflict of Interest}

None declared

\section{References}

1. Locker D, Ford J (1996) Using area-based measures of socioeconomic status in dental health services research. J Public Health Dent 56: 69-75. [Crossref]

2. Locker D (2000) Deprivation and oral health: a review. Community Dent Oral Epidemiol 28: 161-169. [Crossref]

3. Locker D (1993) Measuring social inequality in dental health services research: individual, household and area-based measures. Community Dental Health 10: 139150 [Crossref]

4. Järvinen VK, Rytömaa II, Heinonen OP (1991) Risk factors in dental erosion. J Dent Res 70: 942-947. [Crossref]

5. Milosevic A, Young PJ, Lennon MA (1994) The prevalence of tooth wear in 14-yearold school children in Liverpool. Community Dent Health 11: 83-86. [Crossref]

6. Milosevic A, Lo MS (1996) Tooth wear in three ethnic groups in Sabah (northern Borneo). Int Dent J 46: 572-578. [Crossref]

7. Kelleher M, Bishop K (1999) Tooth surface loss: an overview. Br Dent J 186: 61-66. [Crossref]

8. Shaw L, Smith AJ (1999) Dental erosion--the problem and some practical solutions. $\mathrm{Br}$ Dent $J$ 186: 115-118. [Crossref]

9. Sun K, Wang W, Wang X, Shi X, Si Y et al. (2017). Tooth wear: a cross-sectional investigation of the prevalence and risk factors in Beijing, China. BDJ Open, 3.

10. [No authors listed] (1990) Diet, nutrition, and the prevention of chronic diseases. Report of a WHO Study Group. World Health Organ Tech Rep Ser 797: 1-204. [Crossref]

11. Masotti S, Bogdanic N, Arnaud J, Cervellati F, Gualdi-Russo E (2017). Tooth wear pattern analysis in a sample of Italian Early Bronze Age population. Proposal of a 3-D sampling sequence. Arch Oral Biol, 74: 37-45. [Crossref]

12. Provatenou E, Kaklamanos EG, Kevrekidou A, Kosma I, Kotsanos N (2016). Erosive Tooth Wear and Related Risk Factors in 8-and 14-Year-Old Greek Children. Caries Res., 50: 349-362. [Crossref]

13. Murakami C, Tello G, Abanto J, Oliveira LB, Bonini GC et al. (2016). Trends in the prevalence of erosive tooth wear in Brazilian preschool children. Int J Paediatr Dent., 26: 60-65. [Crossref]

14. Alaraudanjoki V, Laitala ML, Tjäderhane L, Pesonen P, Lussi A et al. (2016) Association of erosive tooth wear and dental caries in Northern Finland Birth Cohort 1966-an epidemiological cross-sectional study. BMC Oral Health, 17(1), 6. [Crossref]

15. Kreulen CM, Van 't Spijker A, Rodriguez JM, Bronkhorst EM, Creugers NH, et al. (2010) Systematic review of the prevalence of tooth wear in children and adolescents. Caries Res 44: 151-159. [Crossref]

16. Sun K, Wang W, Wang X, Shi X, Si Y et al. (2017). Tooth wear: a cross-sectional investigation of the prevalence and risk factors in Beijing, China. BDJ Open, 3.
17. Oral health in America: a report of the surgeon general. US Public Health Service, 2000

18. Carmichael C, French A, Rugg-Gunn A, Furness J. (1984) The relationship between social class and caries experience in five-year-old children in Newcastle and Northumberland after twelve years' fluoridation. Community Dent Health 1:47-54

19. Evans DJ, Rugg GA, Tabari ED, Butler T (1996) The effect of fluoridation and social class on caries experience in 5-year-old Newcastle children in 1994 compared with results over the previous 18 years. Community Dent Health 13:5-10 [Crossref]

20. Gilbert GH, Duncan R, Vogel WB (1998) Six months of dental care use in dentate adults: six months use during a 24-month period in the Floridian Dental Care Study. Soc Sci Med 47:727-37

21. ibson GB, Blasberg B, Hill SJ (1993). A prospective survey of hospital ambulatory dental emergencies. Part 1: patient and emergency characteristics. Spec Care Dentist 13:61-5 [Crossref]

22. McGrath C, Bedi R (2004) The association between dental anxiety and oral healthrelated quality of life in Britain. Community Dent Oral Epidemiol 32:67-72 [Crossref]

23. Johansson A, Fareed K, Omar R (1991) Analysis of possible factors influencing the occurrence of occlusal tooth wear in a young Saudi population. Acta Odontol Scand, 49: 139-145 [Crossref]

24. Murad B, Sepah NG, Basheer-Rehman TA Parafunctional Habits Among Undergraduate Clinical Students And House Officers At Khyber College Of Dentistry. Cell, 333, 9671239 .

25. Feteih RM (2006). Signs and symptoms of temporomandibular disorders and ora parafunctions in urban Saudi Arabian adolescents: a research report. Head Face Med, 2: 25. [Crossref]

26. Al-Dlaigan YH, Shaw L, Smith, A. (2001). Tooth surface loss: Dental erosion in a group of British 14-year-old, school children. Part I: Prevalence and influence of differing socioeconomic backgrounds. British Dental Journal, 190: 145-149.

27. Moshkowitz M, Horowitz N, Halpern Z, Santo E. (2011). Gastroesophageal reflux disease symptoms: prevalence, sociodemographics and treatment patterns in the adult Israeli population. World J Gastroenterol, 17: 1332-1335.

28. El-Serag HB, Petersen NJ, Carter J, Graham DY, Richardson P et al. (2004) Gastroesophageal reflux among different racial groups in the United States. Gastroenterology 126: 1692-1699

29. Diaz-Rubio M, Moreno-Elola-Olaso C, Rey E, Locke GR 3rd, Rodriguez-Artalejo F. (2004) Symptoms of gastro-oesophageal reflux: prevalence, severity, duration and associated factors in a Spanish population. Aliment Pharmacol Ther 19: 95-105 [Crossref]

30. Nokon M, Keil T, Willich SN. (2006) Prevalence and sociodemographics of reflux symptoms in Germany--results from a national survey. Aliment Pharmacol Ther 23: 1601-1605 [Crossref]

31. Jansson C, Nordenstedt H, Johansson S, Wallander MA, Johnsen R et al. (2007) Relation between gastroesophageal reflux symptoms and socioeconomic factors: a population-based study (the HUNT Study). Clin Gastroenterol Hepatol 5: 1029-1034 [Crossref]

32. Gomes SG, Custodio W, Faot F, Cury AA, Garcia RC. (2011) Chewing side, bite force symmetry, and occlusal contact area of subjects with different facial vertical patterns. Braz Oral Res. 25: 446-452 [Crossref]

33. Wei Z, Du Y, Zhang J, Tai B, Du M, et al. (2016) Prevalence and Indicators of Tooth Wear among Chinese Adults. PLoS One 11: e0162181. [Crossref]

Copyright: (C2017 Baber H. This is an open-access article distributed under the terms of the Creative Commons Attribution License, which permits unrestricted use, distribution, and reproduction in any medium, provided the original author and source are credited. 